\title{
Migratory dichotomy and associated phenotypic variation in marine turtles revealed by satellite tracking and stable isotope analysis
}

\author{
Judith A. Zbinden ${ }^{1,4}$, Stuart Bearhop ${ }^{1}$, Philip Bradshaw ${ }^{2}$, Bronwen Gill' ${ }^{2}$, \\ Dimitris Margaritoulis ${ }^{2}$, Jason Newton ${ }^{3}$, Brendan J. Godley ${ }^{1, *}$ \\ ${ }^{1}$ Centre for Ecology and Conservation, School of Biosciences, University of Exeter, Cornwall Campus, Penryn, \\ Cornwall TR10 9EZ, UK \\ ${ }^{2}$ ARCHELON, the Sea Turtle Protection Society of Greece, Solomou, 10432 Athens, Greece \\ ${ }^{3}$ NERC Life Sciences Mass Spectrometry Facility, Scottish Universities Environmental Research Centre, Rankine Avenue, \\ East Kilbride G75 0QF, UK \\ ${ }^{4}$ Present address: Hochfeldstrasse, 3012 Bern, Switzerland
}

\begin{abstract}
Linking foraging and breeding habitats is key to the understanding of behaviour, ecology and demography of migratory species. Establishing such connections has long been hampered by the logistical problems of following individuals between foraging and breeding areas, especially in the marine realm. We used variation in nitrogen stable isotope patterns between 2 foraging regions of loggerhead sea turtles Caretta caretta determined from samples of satellite-tracked individuals to assign untracked turtles to a foraging region. We sought to enhance determination of the relative importance of geographically separated foraging regions and to investigate the relationship between fitness correlates and inferred migratory strategies. Of 18 turtles followed by satellite tracking from Zakynthos (Greece), 10 moved north to foraging areas in the Adriatic Sea and the Gulf of Amvrakikos and 8 moved south to foraging areas off the coast of North Africa. Of 51 untracked individuals sampled for stable isotope analysis, we considered the stable isotope signature of 47 to qualify for assignment to foraging areas in the north $(\mathrm{n}=22)$ and south $(\mathrm{n}=25)$. Females foraging north were significantly larger (curved carapace length), and the former group laid larger clutches (even after correction for body length) than turtles foraging south, a fact that can be interpreted as a carry-over effect. Combining satellite tracking with stable isotope signatures in marine turtles opens new perspectives into how forensic tracking methodologies may be used to scale up knowledge from electronic tracking of a limited number of individuals to sample sizes that are more meaningful from a population perspective.
\end{abstract}

KEY WORDS: Migration · Carry-over effect · Stable isotope · Satellite tracking · Mediterranean · Loggerhead sea turtle $\cdot$ Caretta caretta

Resale or republication not permitted without written consent of the publisher

\section{INTRODUCTION}

Migration is a fundamental aspect of life in a wide range of marine and terrestrial animal species, and understanding intraspecific variation in migratory strategies in the context of the entire migratory cycle is of great interest. In particular, how processes in dis- tinct habitats influence each other through so-called carry-over effects (Marra et al. 1998, Bearhop et al. 2005, Norris 2005) is crucial in grasping the ecology, demography, life history and conservation needs of populations (Webster et al. 2002, Wilcove \& Wikelski 2008). Understanding the links between foraging and breeding areas requires tracking of individuals 
between these areas. Such tracking is often difficult to accomplish, especially in migratory marine species (Block et al. 2005).

A number of studies on birds have relied on intrinsic markers such as stable isotopes acquired with the assimilation of ingested food (see Inger \& Bearhop 2008 for a review), assigning individuals sampled in the breeding area to wintering areas according to known natural patterns of geographic variation in stable isotopes (so called isoscapes; Bowen et al. 2005 and references therein). Stable isotopes cannot be as readily applied to animals in marine habitats as, in comparison to terrestrial systems, information on marine isoscapes at the scale over which these animals move is scarce and/or only applicable to specific environmental conditions (Quillfeldt et al. 2005).

Notwithstanding, stable isotope analysis, particularly in conjunction with complementary techniques, is playing an increasing role in elucidating aspects of the ecology, demography and ultimately conservation needs of migratory marine species (e.g. Cory's shearwaters Calonectris diomedea: Ramos et al. 2009; Atlantic bluefin tuna Thunnus thynnus: Rooker et al. 2008; Pacific humpback whales Megaptera novaeangliae: Witteveen et al. 2009).

In cheloniid sea turtles, each adult female from a colonial nesting area typically forages in one of a number of geographically distinct foraging regions in waters above the continental shelf usually located at considerable distances from the breeding area (reviewed by Plotkin 2003). Individuals are thought to show fidelity to both the breeding and foraging area throughout their adult life (Bowen et al. 1992, Broderick et al. 2007). As capital breeders (accumulating energy for reproduction in the non-breeding areas; Sterns 1992), marine turtles typically only reproduce every few years, but lay several clutches of eggs during a given nesting season (Miller 1997), likely after having reached a critical threshold body condition (Hays 2000). This trait means that carry-over effects may play an important role in the ecology of sea turtles, as the resources required for reproduction are acquired months before the breeding season and far from the breeding location (Hamann et al. 2003).

Satellite tracking has become the predominant method to investigate migration in marine turtles, but is usually restricted to low sample sizes (reviewed in Godley et al. 2008) mainly due to the very high cost per individual tracked (ca. USD 5000 to 10000 per animal depending on transmitter model and longevity of tracking). There is clearly a need to utilize complimentary methods to increase the impact of what can be ascertained using this technique, with stable isotope analysis offering strong potential. Studies in this taxon have already shown that stable isotope patterns can be used to gain insights into foraging ecology highlighting interspecific differences (Godley et al. 1998), intraspecific dichotomies (Hatase et al. 2002, 2006, Wallace et al. 2006, Caut et al. 2008, Reich et al. 2010) and developmental habitat shifts (Reich et al. 2007, Arthur et al. 2008, McClellan et al. 2010).

We set out to develop an approach of matching distant foraging and breeding areas by analysing stable isotope patterns of satellite-tracked individuals with the aim of assigning non-satellite-tracked individuals to foraging areas. In addition to scaling up knowledge on relative foraging area use from limited sample size of satellite-tracked individuals, we sought to explore whether variation in individual characteristics observed in the breeding area (such as female size and clutch size) are associated with different migratory strategies, thus explaining part of the considerable variation in such phenotypic characteristics observed in the breeding area.

We chose the largest breeding population of Mediterranean loggerhead sea turtles Caretta caretta nesting on Zakynthos, Greece $\left(37^{\circ} 42^{\prime}\right.$ to $37^{\circ} 44^{\prime} \mathrm{N}$,

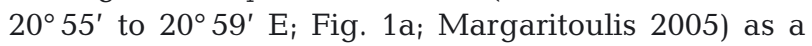
model breeding population. Preliminary information on migratory patterns of this breeding population gained through recapture data of flipper-tagged females (Margaritoulis et al. 2003) and limited satellite tracking (Zbinden et al. 2008) had indicated 2 geographically separated coastal foraging regions (the Adriatic Sea and the Gulf of Gabès off North Africa; locations see Fig. 1a). The geographical separation and distinct ecological conditions (see references in Zbinden et al. 2008) of these 2 foraging locations present promising preconditions to find variation in stable isotope patterns.

\section{MATERIALS AND METHODS}

Satellite tracking. We tracked 18 adult female loggerhead turtles following nesting at the Bay of Laganas on Zakynthos in the nesting seasons of 2004, 2005 and 2007 (Table 1). Except for 1 individual (Turtle G), transmitters were attached at the height of the nesting season, therefore minimising potential bias that might be introduced in choosing individuals nesting at the limits of the season (Godley et al. 2008, Rees et al. 2010). Transmitters were Sirtrack KiwiSat 101 (Turtles A to G and P to R) and Telonics A-2010 (Turtles $\mathrm{H}$ to $\mathrm{O} ;$ Table 1). For programming and attachment procedures of 2004 and 2005 transmitters, see Zbinden et al. (2008). Transmitters used in 2007 had an output of $0.5 \mathrm{~W}$ and were programmed to emit signals every 40 (Telonics) and $45 \mathrm{~s}$ (Kiwisats) once units were aerially exposed during surfacing behaviour. Attachment 

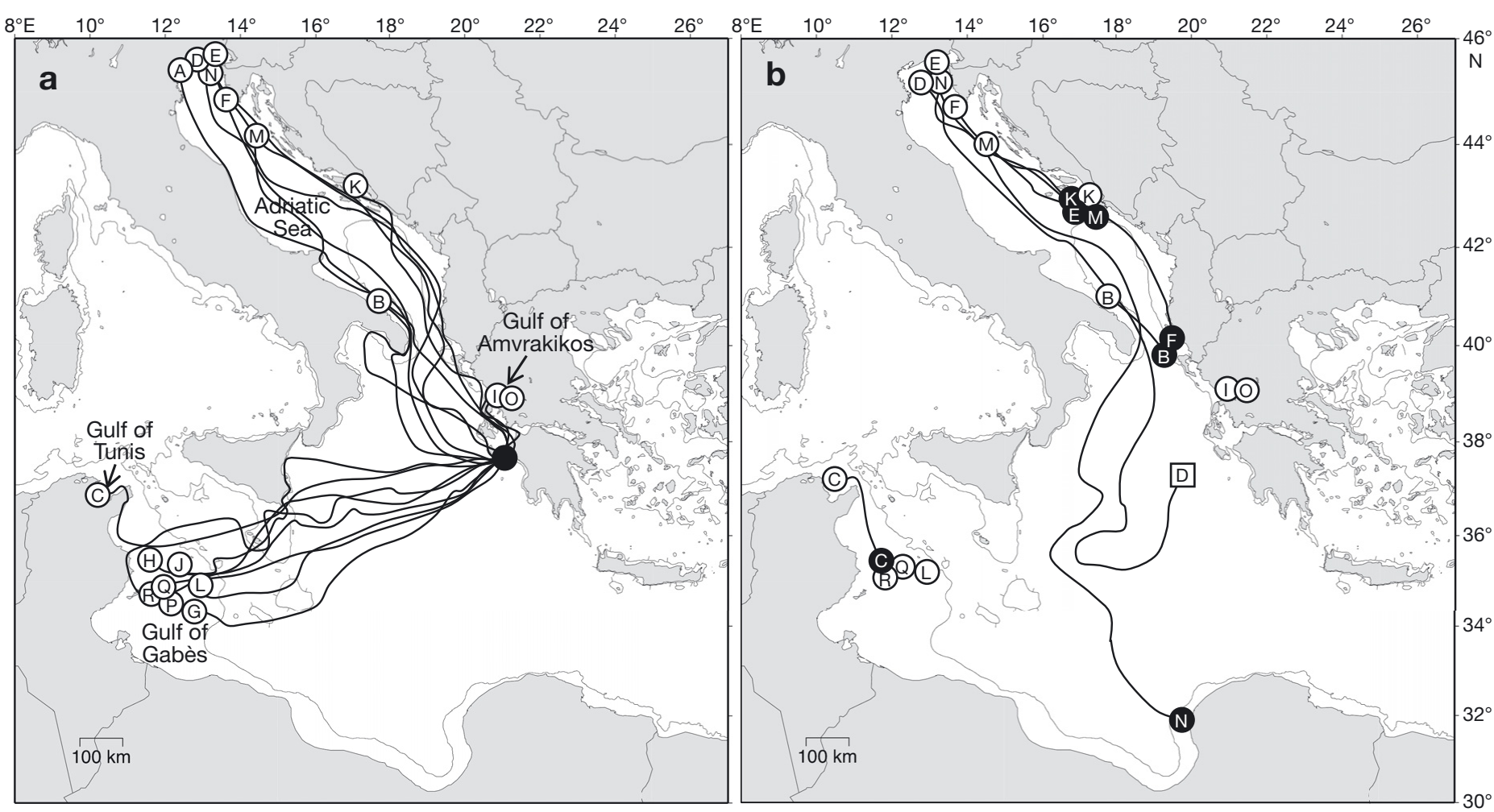

Fig. 1. Caretta caretta. (a) Reconstructed routes to foraging areas (labelled circles) for all turtles from release location on Zakynthos (black dot). The $250 \mathrm{~m}$ isobath is delineated. (b) Reconstructed routes from foraging areas (open circles) to wintering areas (filled circles) or until end of transmissions prior to having reached a wintering area (open square for Turtle D tracked until 22 December 2005, when transmissions ceased) for turtles whose transmitters provided at least 1 location class (LC) 3,2,1 in November to March and lower accuracy locations confirming the general location. The $250 \mathrm{~m}$ isobath is delineated

Table 1. Caretta caretta. Information on satellite tracking and foraging area choice of 18 satellite-tracked loggerheads. The study includes the previously published data on 7 turtles (Individuals A-G; Zbinden et al. 2008). Location data (LCs 3, 2, 1, A and B) in foraging and wintering areas were processed according to the following protocol: locations $\geq 10 \mathrm{~m}$ above sea level were excluded, next locations necessitating a speed exceeding $5 \mathrm{~km} \mathrm{~h}^{-1}$ were filtered, and then locations requiring a turning angle $<30^{\circ}$ were omitted. From this data set, the location of the best LC per day was retained. CCL: curved carapace length; PTT: platform terminal transmitter

\begin{tabular}{|c|c|c|c|c|c|c|c|c|c|c|}
\hline Ind. & $\begin{array}{l}\text { CCL } \\
(\mathrm{cm})\end{array}$ & $\begin{array}{c}\text { PTT } \\
\text { deployment } \\
\text { date } \\
\text { (yy-mm-dd) }\end{array}$ & $\begin{array}{c}\text { Transmitter } \\
\text { type }\end{array}$ & $\begin{array}{l}\text { Postnesting } \\
\text { migration } \\
\text { distance }(\mathrm{km})\end{array}$ & $\begin{array}{c}\text { Postnesting } \\
\text { displacement } \\
(\mathrm{km})\end{array}$ & $\begin{array}{c}\text { Foraging } \\
\text { area }\end{array}$ & $\begin{array}{c}\text { Arrival date } \\
\text { in foraging } \\
\text { area } \\
\text { (yy-mm-dd) }\end{array}$ & $\begin{array}{c}\text { Date of } \\
\text { departure or } \\
\text { PTT cessation } \\
\text { (yy-mm-dd) }\end{array}$ & $\begin{array}{l}\text { Entire } \\
\text { tracking } \\
\text { duration } \\
\text { (d) }\end{array}$ & $\begin{array}{c}\text { Depth } \\
\text { (m) }\end{array}$ \\
\hline A & 85 & $2004-06-28$ & Kiwisat & 1159 & 1105 & Adriatic Sea & $2004-09-16$ & $2004-10-30$ & 44 & 20 \\
\hline $\mathrm{B}$ & 86 & $2004-06-29$ & Kiwisat & 697 & 443 & Adriatic Sea & $2004-08-12$ & $2004-10-31$ & 80 & 5 \\
\hline $\mathrm{C}$ & 91 & $2004-06-30$ & Kiwisat & 1042 & 942 & Gulf of Gabès & $2004-09-06$ & 2004-11-12 & 67 & 0 \\
\hline $\mathrm{F}$ & 89 & $2005-06-22$ & Kiwisat & 1072 & 997 & Adriatic Sea & $2005-09-05$ & $2005-10-20$ & 45 & 40 \\
\hline $\mathrm{G}$ & 76 & $2005-08-10$ & Kiwisat & 855 & 789 & Gulf of Gabès & $2005-08-31$ & 2005-11-11 & 72 & 98 \\
\hline $\mathrm{H}$ & 86 & $2007-07-09$ & Telonics & 1116 & 852 & Gulf of Gabès & $2007-09-07$ & $2007-10-29$ & 52 & 89 \\
\hline $\mathrm{I}$ & 86 & $2007-07-10$ & Telonics & 150 & 143 & Gulf of Amvrakikos & $2007-08-26$ & $2008-05-21$ & 269 & 5 \\
\hline $\mathrm{J}$ & 82 & $2007-07-11$ & Telonics & 1015 & 786 & Gulf of Gabès & $2007-07-29$ & $2007-09-09$ & 42 & 35 \\
\hline $\mathrm{K}$ & 85 & 2007-07-11 & Telonics & 813 & 678 & Adriatic Sea & $2007-08-12$ & $2007-09-08$ & 27 & 5 \\
\hline $\mathrm{L}$ & 79 & 2007-07-12 & Telonics & 813 & 762 & Gulf of Gabès & $2007-08-20$ & 2008-09-11 & 388 & 104 \\
\hline $\mathrm{Q}$ & 82 & $2007-07-25$ & Kiwisat & 1040 & 821 & Gulf of Gabès & $2007-10-04$ & $2008-03-01$ & 149 & 50 \\
\hline $\mathrm{R}$ & 78 & $2007-07-26$ & Kiwisat & 1348 & 899 & Gulf of Gabès & $2007-09-06$ & $2009-05-28$ & 630 & 14 \\
\hline
\end{tabular}


procedures in 2007 followed those of 2005. We located turtles through the Argos system (www.argosinc.com) and downloaded, managed and analysed data using the Satellite Tracking and Analysis Tool (STAT; Coyne \& Godley 2005). Behaviour (post-nesting migration, foraging, migration to wintering area, wintering) was determined by inflection points in plots of displacement from the release site over time (Blumenthal et al. 2006).

The median centroid point from each foraging and wintering area was determined from which sea floor depth was recorded. For source and resolution of these data, see Coyne \& Godley (2005). Due to the large variation in location frequency and time period over which location data were received, home range calculations are not considered to be sufficiently reliable for comparison among individuals.

Sample and field data collection. Sample collection and recording of fitness-related parameters were conducted in the context of a multi-decadal monitoring program implemented by ARCHELON (The Sea Turtle Protection Society of Greece). This program includes consistent monitoring of nesting and hatching activity including following individual clutches throughout incubation and excavation of clutches $14 \mathrm{~d}$ after first emergence of hatchlings to determine hatching success. Additionally, a fraction of nesting females are observed, measured and flipper-tagged during night patrols (Margaritoulis 2005, Rees 2005).

We collected data on female length (curved carapace length; CCL) at nesting and number of eggs per clutch at post-hatching excavation from a representative sample of nesting females observed. From the clutches of study females, at least 1 undeveloped egg was collected at post-hatching clutch excavation and a sample of yolk (about $1 \mathrm{ml}$ ) retrieved. Yolk from undeveloped eggs retrieved at post-hatching clutch excavation was chosen as the main tissue type for stable isotope analysis because it can be sampled widely and non-intrusively without causing disturbance to nesting females, nest structure or negatively impacting hatchling production. Egg samples were only included if the clutch could be assigned with certainty to a given female (for methods matching hatched to laid clutches see Zbinden et al. 2007a). For various reasons, it might be impossible to get an undeveloped egg from a given clutch at post-hatching clutch excavation. Therefore, to guarantee we had a voucher from each individual satellite tracked in 2007, we obtained a fresh egg at laying from these 11 turtles. The removal of a total of 11 eggs was considered justified considering that on average over 1200 clutches are laid at this rookery with on average 116 eggs per clutch (Margaritoulis 2005). The availability of yolk retrieved at laying and at post- hatching clutch excavation from a number of the clutches of satellite-tracked individuals allowed an assessment of the viability of using yolk obtained at post-hatching clutch excavation. To investigate intraindividual (both within and between clutches of a given female) variation in egg stable isotope values within one nesting season, we also collected several eggs at excavation from a small number of clutches as well as from multiple clutches for a number of females. In addition, carapace keratin was sampled in some turtles. Eggs (retrieved both at laying and at post-hatching clutch excavation) that were obviously very degraded or demonstrating abnormal yolk colouring were excluded. Samples were frozen within $12 \mathrm{~h}$ of collection and stored frozen until processing.

All aspects of field work were approved by the Greek Ministry of Agriculture.

Sample preparation and stable isotope analysis. The defrosted yolk samples were dried at $60^{\circ} \mathrm{C}$ for $48 \mathrm{~h}$ and ground to powder before lipids were extracted using a Soxhlet apparatus with a 2:1 chloroformmethanol mix. Carapace samples were rinsed with deionised water, dried at $60^{\circ} \mathrm{C}$ for $48 \mathrm{~h}$ and cut into small pieces. Approximately $0.7 \mathrm{mg}$ of the prepared tissue was weighed into tin capsules. Carbon and nitrogen stable isotope ratios were analysed by continuous-flow isotope ratio mass spectrometry (IRMS) using a Costech ECS4010 elemental analyser connected via an interface (Conflo III) to a Thermo Fisher Scientific Delta V Plus isotope ratio mass spectrometer. Isotope ratios are expressed in parts per thousand (\%o) according to the equation $\delta X=\left[\left(R_{\text {sample }} / R_{\text {standard }}\right)-1\right] \times$ 1000 , where $X$ is ${ }^{15} \mathrm{~N}$ and ${ }^{13} \mathrm{C}$ and $R$ is the corresponding ratio of the heavier to the lighter isotope (i.e. ${ }^{15} \mathrm{~N} /{ }^{14} \mathrm{~N}$ and ${ }^{13} \mathrm{C} /{ }^{12} \mathrm{C}$ ). International standards in the delta equation for $\mathrm{C}$ and $\mathrm{N}$ isotope ratios were Pee Dee Belemnite and AIR, respectively. Replicate measurements of internal laboratory standards indicated analytical error of $0.1 \%$ for $\delta^{13} \mathrm{C}$ and $0.2 \%$ for $\delta^{15} \mathrm{~N}$. All stable isotope analyses were performed at the UK Natural Environment Research Council Life Sciences Mass Spectrometry Facility, East Kilbride.

Statistical tests were conducted with the program R (R Development Core Team 2007). A linear model was used to test for a confounding association between $\delta^{15} \mathrm{~N}$ and female length (dependent variable: $\delta^{15} \mathrm{~N}$, explanatory variables: turtle length, foraging area, interaction between turtle length and foraging area). A $t$-test was conducted to test for differences in body length between females of the 2 migratory strategies (dependent variable: turtle length, explanatory variable: foraging area). Finally, we tested for differences in clutch size between females presumed to be using different foraging areas (linear model; dependent vari- 
able: clutch size, explanatory variables: turtle length, foraging area, interaction between turtle length and foraging area). As clutch size is known to correlate with carapace length in marine turtles (e.g. Broderick et al. 2003), we corrected for carapace length by adding this parameter as a covariate in the model. Assumptions of normality were confirmed a posteriori for all tests.

\section{RESULTS}

\section{Satellite tracking}

The movement patterns showed clear behavioural episodes of post-nesting migration and resident foraging for all tracked turtles in areas above the continental shelf (Fig. 1a, Table 1). Additionally, for those individuals with foraging areas beyond $44^{\circ} \mathrm{N}$, migration to wintering areas and extended residence in these locations for some individuals was demonstrated (Fig. 1b). The considerably enhanced sample size of satellitetracked turtles from the Zakynthos rookery confirms the Adriatic Sea and the north African coast around the Gulf of Gabès/Gulf of Tunis as the 2 main foraging regions for this population, with 8 turtles foraging in each of these (Fig. 1a). Additionally, 2 females migrated to the Gulf of Amvrakikos, a shallow bay in northern Greece where adult females tagged on the nesting beaches of Zakynthos have previously been observed foraging (Casale \& Margaritoulis 2010). We classified turtles into 2 migratory strategies, according to whether they migrated 'north' or 'south' following breeding.

\section{Stable isotope analysis}

\section{Methodological validation}

From 5 satellite-tracked turtles, fresh yolk and yolk at excavation from the same clutch was available. The comparison of stable isotope values between excavation and fresh yolk revealed that for $\delta^{15} \mathrm{~N}$, excavation yolk was consistently slightly enriched compared to fresh yolk (mean $\pm \mathrm{SD}=0.49 \pm 0.22 \%$; range $=0.21$ to $0.74 \%$ ). For $\delta^{13} \mathrm{C}$, there was no consistent pattern in difference between excavation and fresh yolk; in 3 cases, excavation yolk was enriched compared to fresh yolk while the opposite was true for 2 clutches. The average difference was $0.20 \pm 0.12 \%$ (range $=0.13$ to $0.38 \%$ ). For satellite-tracked females for which fresh and excavation yolk was available, fresh yolk was not considered in data presentation and analysis, as we sought to use the voucher for which we had greatest sample coverage. In addition, for 3 females (Turtles I, P and R), only fresh yolk was available, and we corrected the $\delta^{15} \mathrm{~N}$ values by the average difference between fresh and excavation yolk $(0.49 \%)$.

Four or more eggs (mean $=8 \pm 1.68$, range per clutch: 4 to 36 eggs) were analysed from 13 clutches of 13 different females. Average differences between eggs within a clutch (average absolute difference between all pairwise comparisons) ranged from 0.01 to $0.4 \%$ (mean $=0.20 \pm 0.11 \%$ ) for $\delta^{15} \mathrm{~N}$ and from 0.09 to $0.35 \%$ o (mean $=0.21 \pm 0.079 \%$ ) for $\delta^{13} \mathrm{C}$.

Yolk samples of more than one clutch laid during the 2007 nesting season were available from 14 females and a total of 31 clutches $(2,3$ and 4 clutches from 12, 1 and 1 female[s], respectively). The average difference among clutches (average absolute difference between all pairwise comparisons) was $0.22 \pm$ $0.17 \%$ (range $=0.01$ to $0.61 \%$ ) for $\delta^{15} \mathrm{~N}$ and $0.21 \pm$ $0.11 \%$ (range $=0.01$ to $0.40 \%$ ) for $\delta^{13} \mathrm{C}$. To investigate whether there was a pattern of depletion or enrichment with consecutive clutches, we conducted a mixed effect model including both intercept and slope (likelihood-ratio test) for $\delta^{15} \mathrm{~N}$ and $\delta^{13} \mathrm{C}$ values separately. For $\delta^{15} \mathrm{~N}$, the model converged well. There was a very small but statistically significant decrease of $\delta^{15} \mathrm{~N}$ values with clutch order (likelihood ratio $[\mathrm{LR}]=6.61 ; \mathrm{df}=1 ; \mathrm{p}=0.01$ ), with ${ }^{15} \mathrm{~N}$ on average becoming depleted by $0.13 \%$ with each successive clutch (Fig. 2a). The model based on $\delta^{13} \mathrm{C}$ values did not converge. As the graphic presentation of the values shows (Fig. 2b), the slopes of $\delta^{13} \mathrm{C}$ differences between clutches were relatively uniform across individuals, and therefore the random slope term could be excluded from the model. The resultant mixed effects model with random intercept converged well. There was a significant decrease of $\delta^{13} \mathrm{C}$ values with clutch order $(\mathrm{LR}=16.3$; df $=1 ; \mathrm{p}<0.001)$, with ${ }^{13} \mathrm{C}$ on average becoming depleted by $0.14 \%$ with each successive clutch. For all presentations and analyses, we used mean isotope values if more than 1 egg per female was sampled at excavation.

Carapace samples were available from the 11 turtles tracked in 2007 and from a subgroup of 16 untracked study individuals. There was a highly significant positive correlation between yolk and carapace samples for $\delta^{15} \mathrm{~N}$ (Spearman rank correlation: coefficient of correlation $r=0.92$; $p<0.001$; Fig. 3a). In line with the reduced coefficient of variation, the correlation for $\delta^{13} \mathrm{C}$ between yolk and carapace is not as highly correlated (Spearman rank correlation: coefficient of correlation $r=0.68 ; \mathrm{p}=0.001$; Fig. 3b). This result should be interpreted with caution, however, due to the unequal distribution of data points across the range, with few very depleted or enriched samples. 

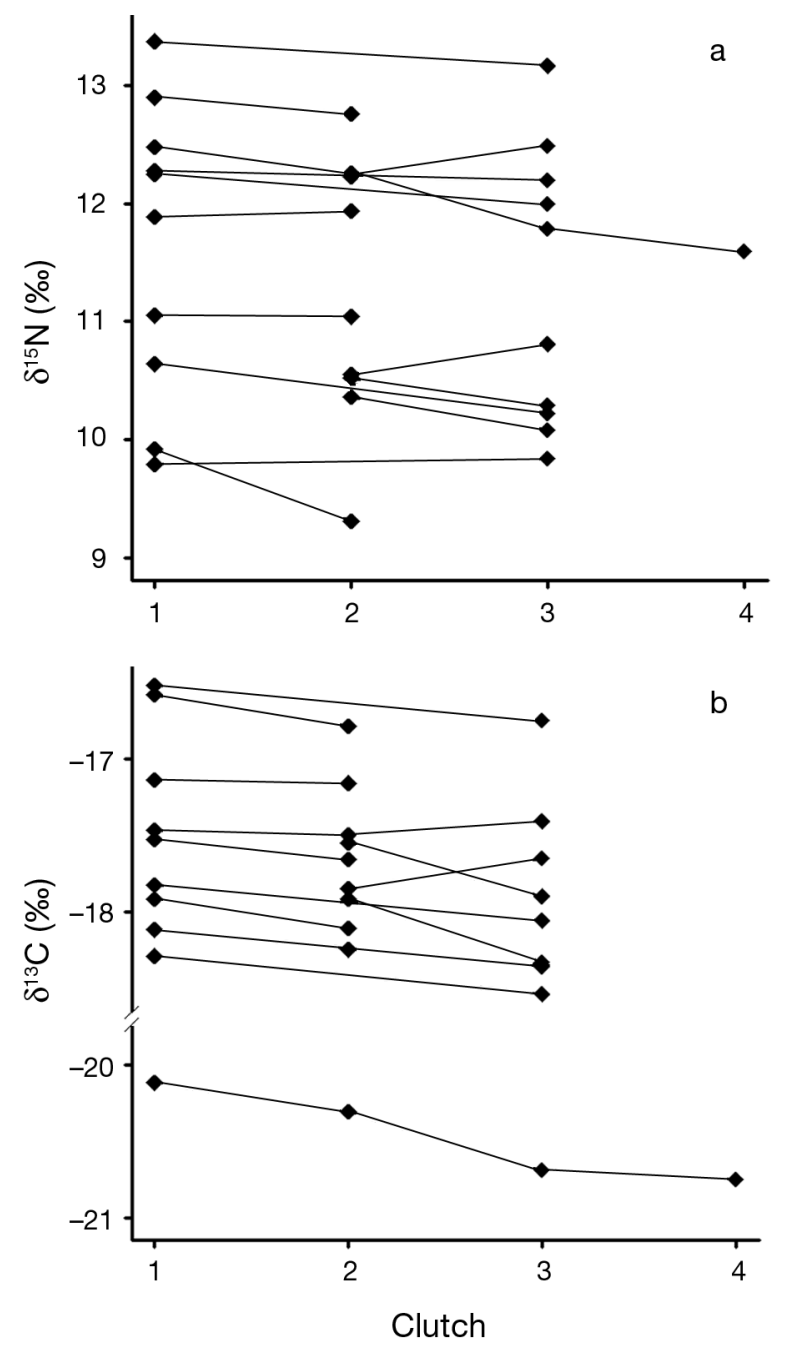

Fig. 2. Caretta caretta. Stable isotope values in egg yolk of consecutive clutches laid by individual females for (a) nitrogen and (b) carbon. Clutch number is an estimate based on the onset of the nesting season and average internesting interval (time period between 2 successive clutches of a female within a nesting season)

Discrimination of stable isotope ratios according to foraging region and assignment of untracked individuals

Yolk samples were available from a total of 63 females. Of these, 12 were satellite tracked (11 tracked in 2007: Turtles $\mathrm{H}$ to $\mathrm{R}_{i} 1$ tracked in 2004 but observed nesting again in 2007: Turtle E) and 51 untracked turtles (Fig. 4a). Six tracked animals for which isotopes were analysed were of the northern (4 foraging in the Adriatic Sea and 2 in the Gulf of Amvrakikos) and 6 of the southern migratory strategy (Table 1). Although there was variation within foraging area, with few notable outliers, a clear picture emerged with isotope
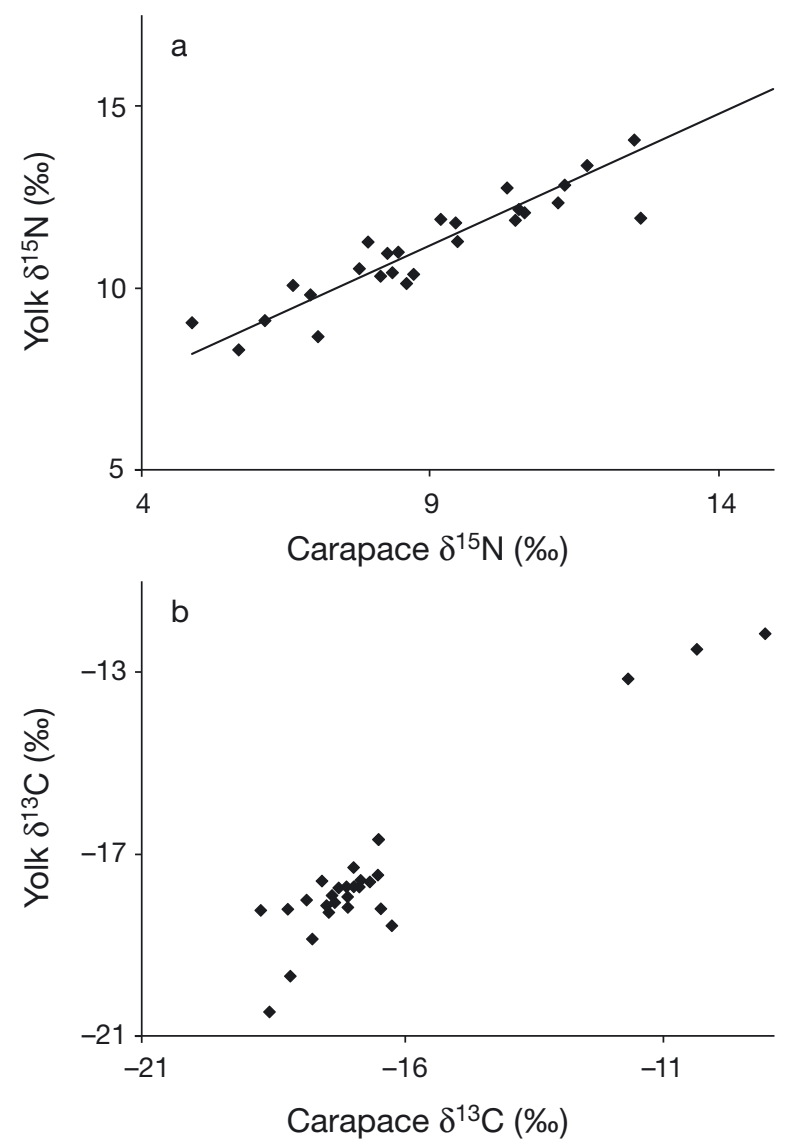

Fig. 3. Caretta caretta. Correlation between yolk and carapace values for (a) $\delta^{15} \mathrm{~N}$ (yolk $=4.69+0.73 \times$ carapace) and (b) $\delta^{13} \mathrm{C}$. The correlation between yolk and carapace $\delta^{15} \mathrm{~N}$ signatures is highly significant (Spearman rank correlation: coefficient of correlation $\mathrm{r}=0.92 ; \mathrm{p}<0.001$ ). The correlation between yolk and carapace $\delta^{13} \mathrm{C}$ signatures is also highly significant (Spearman rank correlation: coefficient of correlation $\mathrm{r}=0.68 ; \mathrm{p}=0.001$ ). The latter result should be interpreted with caution, however, due to the unequal distribution of data points across the range

values of turtles foraging in the north being enriched in ${ }^{15} \mathrm{~N}$ with respect to those of the southern foraging area (Fig. 4b). There was no apparent pattern of differentiation in $\delta^{13} \mathrm{C}$ values by foraging region (Fig. 4b). We therefore based the assignment of untracked turtles solely on $\delta^{15} \mathrm{~N}$ yolk values, defining thresholds visually from Fig $4 \mathrm{~b}$. Individuals with $\delta^{15} \mathrm{~N}$ values of $11.0 \%$ or below were considered foraging 'south', while turtles with $\delta^{15} \mathrm{~N}$ values of $11.5 \%$ or above were considered as foraging in the 'north' (Fig. 5). Four individuals were considered impossible to assign because of the slight overlap of values in the range of $\delta^{15} \mathrm{~N}$ between 11.0 and $11.5 \%$. Of the remaining 47 untracked individuals, 22 (43\% of all sampled turtles) were considered as foraging in the north and 25 (49\% of all sampled tur- 

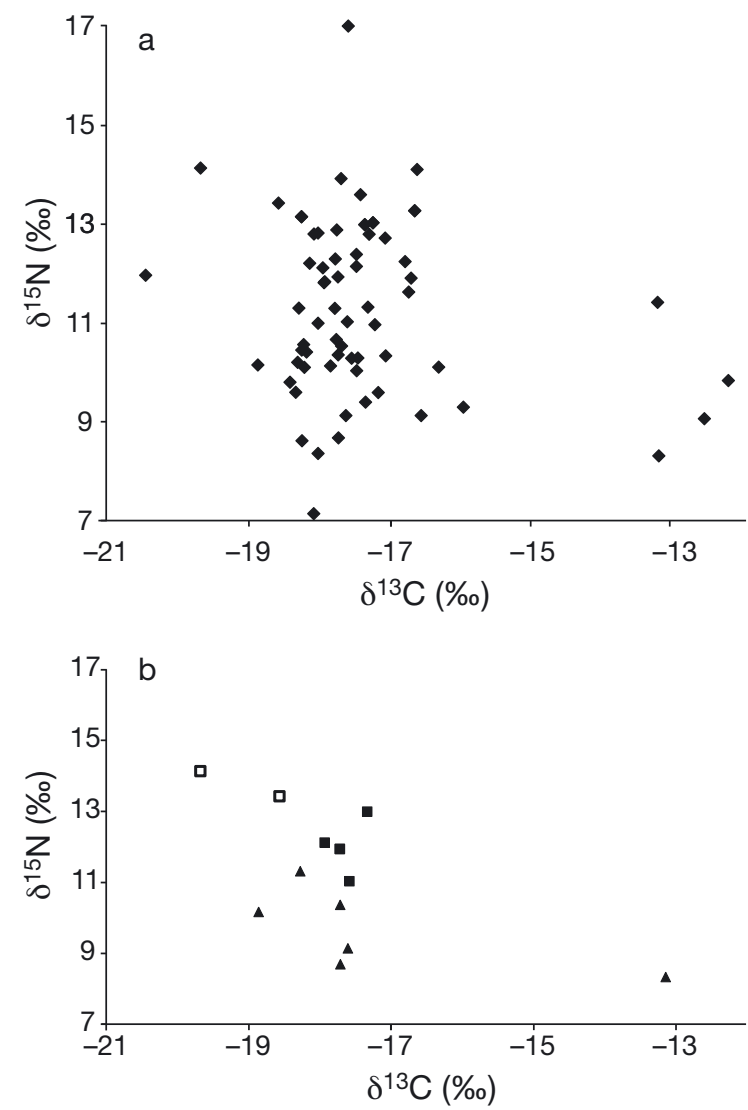

Fig. 4. Caretta caretta. (a) Distribution of stable isotope values in the full dataset of egg yolk retrieved at clutch excavation. (b) Distribution of egg yolk stable isotope values according to known foraging area for the 12 satellite-tracked individuals for which a voucher for stable isotope analysis was available. Squares represent turtles foraging in the north (open squares: Gulf of Amvrakikos) and triangles those foraging in the south

tles) as foraging in the south (Fig. 5). Pooled with the satellite-tracked females ( $\mathrm{N}=69$ including those considered impossible to assign to a region), 35 (51\%) presumably foraged in the north and $30(43 \%)$ in the south. If we would more conservatively consider individuals with an extended range, $\delta^{15} \mathrm{~N} 10.5$ to $12 \%$, as unassignable $(\mathrm{N}=13)$, the relative proportions assigned to the 2 foraging regions stayed remarkably similar, with 17 (33\% of all sampled individuals) and 21 (41\% of all sampled individuals) turtles assigned to north and south, respectively.

\section{Fitness parameters related to foraging area}

When foraging area was considered in the model, no effect of body size (carapace length) could be detected on $\delta^{15} \mathrm{~N}$ (carapace length: $F_{1,51}=0.01 ; \mathrm{p}=0.91$; foraging region: $F_{1,51}=102 ; \mathrm{p}<0.001$; interaction between foraging region and carapace length: $F_{1,50}=2.06, \mathrm{p}=$

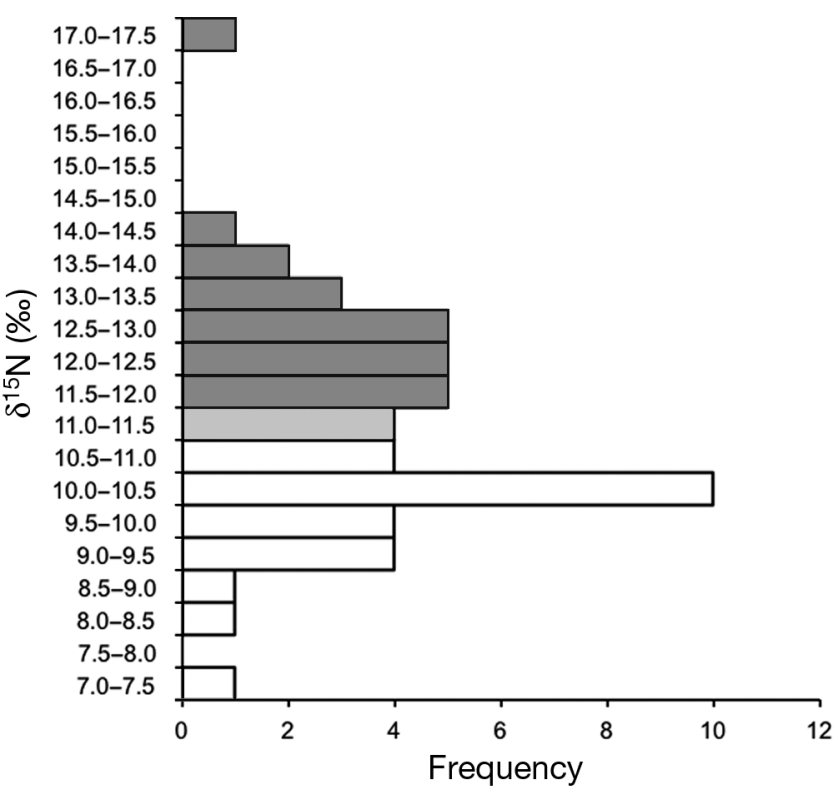

Fig. 5. Caretta caretta. Assignment of untracked turtles $(\mathrm{N}=$ 51 ) to foraging areas according to $\delta^{15} \mathrm{~N}$ of egg yolk (see 'Results' section for details). White bars: southern foraging areas; dark grey bars: northern foraging areas; light grey bar: unassigned

0.16). Turtles foraging north were significantly larger (by on average $2.9 \mathrm{~cm}$ ) than those foraging south $\left(t_{58}=\right.$ 2.40, p =0.020; Fig. 6).

In the model testing for an association between clutch size and foraging area, the interaction term between turtle length and foraging area was not significant $\left(F_{1,55}=0.21, \mathrm{p}=0.65\right.$; meaning that the slope of the relationship between clutch size and female length was not significantly different between the 2 foraging areas) and was thus omitted from the model. As expected, female length explained a significant proportion of variation in clutch size $\left(F_{1,56}=21.3, \mathrm{p}<\right.$ 0.001). Foraging area also had a significant effect on clutch size, with females of the northern migratory strategy laying on average 11.6 eggs more at a given carapace length than females foraging south $\left(F_{1,56}=\right.$ 5.0, $\mathrm{p}=0.029$; Fig. 6).

\section{DISCUSSION}

Our combination of satellite tracking and stable isotope analysis has provided a powerful means of linking different phases of the migration cycle of a widely distributed marine vertebrate. The approach allowed a dramatic scaling up of knowledge gained from a limited number of individuals tracked by satellite and offers a range of methodological and ecological insights. 


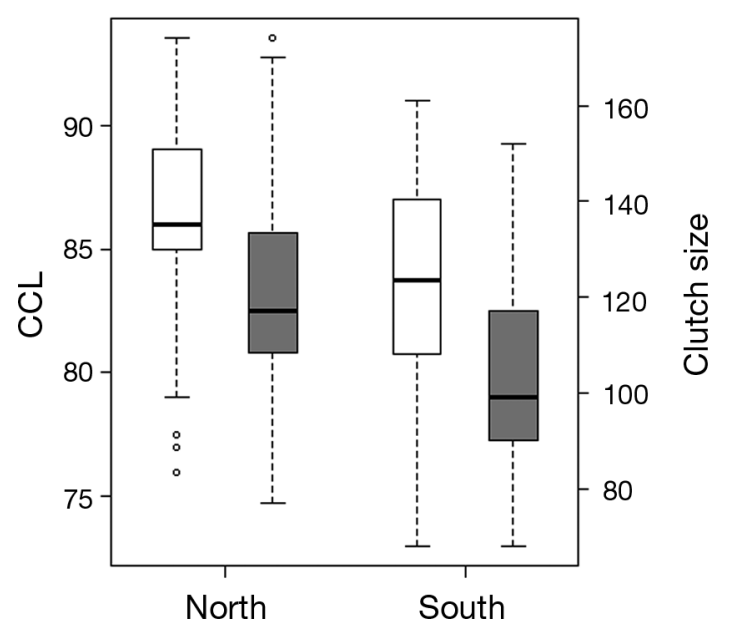

Fig. 6. Caretta caretta. Relationship between fitness proxies and foraging area. Boxplots of female length (curved carapace length, CCL; white bars and left axis) and clutch size (grey bars and right axis) for both foraging areas. Horizontal bar $=$ median; box $=50 \%$ range; whiskers = range of observations within 1.5 times the interquartile range from the edge of the box; circle = observation farther than 1.5 times the interquartile range from the edge of the box. Both CCL and clutch size differed significantly between groups of turtles foraging in the north and south, respectively

\section{Methodological validation}

The comparison between fresh yolk and yolk retrieved at excavation revealed what seems to be a systematic enrichment of yolk at clutch excavation compared to fresh yolk. The difference may be caused by biological degradation or the longer storage of the fresh yolk samples (by the incubation duration +14 d, i.e. up to ca. $70 \mathrm{~d}$ ) as demonstrated by Barrow et al. (2008). Although the differences were relatively trivial from the context of the current study, our sample size for this comparison was rather low. This was driven by the ethical imperative of destroying as few viable eggs as possible. Clearly, this issue could be further addressed.

Slight differences were also found within and among clutches of the same female; again, although interesting, they do not hold great relevance to the current study because the effect was so low in magnitude. A systematic change in stable isotope values with the progression of the nesting season was previously observed by Hatase et al. (2006), who found that ${ }^{15} \mathrm{~N}$ became enriched in one green sea turtle Chelonia mydas for which eggs of consecutive clutches were sampled, and Caut et al. (2008) observed a significant depletion of ${ }^{13} \mathrm{C}$ in consecutive clutches of leatherback sea turtles Dermochelys coriacea. Based on this result combined with stable isotope characterisation of prey off the nesting beach, Caut et al. (2008) rejected the hypothesis of foraging during the internesting period.
For our study, we lack information on isotope patterns in potential prey items in the breeding area. However, evidence of restricted internesting movements (Schofield et al. 2007, Zbinden et al. 2007b) and low productivity in the internesting habitat and low frequency of foraging behaviour directly observed (Schofield et al. 2006) make foraging highly unlikely as an explanation for the observed patterns in our study. Rather, we suspect that biochemical processes during egg formation favouring the incorporation of heavy isotopes may be responsible.

Finally, the significant correlation between carapace and yolk stable nitrogen signatures indicates that carapace holds potential as suitable voucher for future studies. Sampling carapace can be considerably easier than sampling yolk and has the additional advantage that life stages other than reproducing females can be sampled. For instance, very little is known regarding males in these species (although see e.g. Schofield et al. 2009). On the other hand, in settings where it is difficult to encounter adults in the breeding area (e.g. remote, low density nesting sites), sampling yolk from undeveloped eggs as a voucher for stable isotope analysis may be more tractable. It is highly recommended that sampling for stable isotopes in multiple tissues is carried out in additional species and populations to strengthen this conclusion.

\section{Variation in stable isotope signatures among individuals}

Most studies using stable isotope analysis to determine the foraging ecology and location of animals use $\delta^{15} \mathrm{~N}$ to infer trophic level while $\delta^{13} \mathrm{C}$ is considered informative for foraging location in terms of terrestrial versus marine or inshore versus offshore ecosystems (reviewed in Hobson 1999, Rubenstein \& Hobson 2004, Reich et al. 2010). In our study, however, it was $\delta^{15} \mathrm{~N}$ that proved the more informative element, with $\delta^{13} \mathrm{C}$ not consistently contributing to the differentiation between the northern and southern foraging regions. Interestingly, the same holds true for the subadult loggerhead turtles investigated by McClellan et al. (2010). Although there could be different foraging strategies between north and south, the variation in $\delta^{15} \mathrm{~N}$ could also be caused by different contributions of various nitrogen sources in the 2 foraging regions. There are higher contributions of anthropogenic sources in the Adriatic Sea from sewage and animal waste, which are highly enriched in ${ }^{15} \mathrm{~N}$ (Hansson et al. 1997, Harrington et al. 1998, Schlacher et al. 2005). The fact that we could not detect a correlation of $\delta^{15} \mathrm{~N}$ with turtle length, when eliminating the effect of foraging area, supports the general thesis that there is a systematic difference 
in $\delta^{15} \mathrm{~N}$ among regions rather than the difference being ultimately caused by differences in body size.

One possible explanation for the one obvious outlier in the $\delta^{15} \mathrm{~N}$ distribution (sample heavily enriched in ${ }^{15} \mathrm{~N}_{\text {; Fig. }}$ 4a) is that this turtle forages at a different trophic level, possibly eating discarded fish (Tomás et al. 2001, Wallace et al. 2009) in addition to the common benthic invertebrate diet of loggerheads (Bjorndal 2003). One of the 2 samples heavily depleted in ${ }^{13} \mathrm{C}$ (Fig. 4a) was tracked to the Gulf of Amvrakikos. This area is extremely shallow and carbon sources may be partly terrestrial, which would explain the depleted values (e.g. Bearhop et al. 1999). We hypothesise that the other (not satellite-tracked) turtle characterised by a markedly depleted ${ }^{13} \mathrm{C}$ signature could also occupy such a microhabitat affected by terrestrial ${ }^{13} \mathrm{C}$ sources. The $\delta^{13} \mathrm{C}$ values of a group of 4 individuals, including tracked Turtle $\mathrm{R}$, are heavily enriched in ${ }^{13} \mathrm{C}$, but differ quite largely in ${ }^{15} \mathrm{~N}$. We suspect that they occupy 1 or more specific foraging location(s) with source carbon being enriched in ${ }^{13} \mathrm{C}$ and in addition (due to the heterogeneity in ${ }^{15} \mathrm{~N}$ ) differ in foraging strategies. Turtle $\mathrm{R}$ presented with an outstandingly heavy barnacle load, which could also imply poor health. Hence, extreme ${ }^{13} \mathrm{C}$ values in this individual might reflect a physiological problem.

\section{Fitness correlates associated with foraging area}

We discovered differences in fitness-related parameters between turtles of the 2 migratory strategies, which are possible carry-over effects. Namely, turtles of the northern migratory strategy were on average longer and laid more eggs at a given length than those of the southern migratory strategy. Interestingly, a dataset of turtles flipper-tagged on the nesting beaches of Zakynthos and recovered in the Adriatic Sea (from about $42^{\circ} \mathrm{N}$ northward; $\mathrm{N}=37$ ) and the Gulf of Gabès $(\mathrm{N}=32$ ) over the course of $>2$ decades (D. Margaritoulis unpubl. data) concords with the results of this study; females found in the Adriatic Sea were significantly larger than those recovered in the Gulf of Gabès (Adriatic Sea: mean \pm SD CCL: $85.3 \pm 4.87 \mathrm{~cm}$; Gulf of Gabès, mean CCL $=81.0 \pm 4.2 \mathrm{~cm} ; t_{68}=3.95, \mathrm{p}$ $<0.001$, difference $=4.7 \mathrm{~cm}$ ). Turtles can grow through adulthood, and thus differences in size could be due to differences in age, but we suggest this is not very plausible given the large difference in size compared to annual growth rates of breeders (Broderick et al. 2003). This is in line with recent work on a loggerhead population in Japan showing dichotomy in migratory strategies (neritic versus oceanic), which is related to size. Hatase et al. (2010) found no statistically significant difference in DNA telomere length (as a proxy for age) in first-time nesters of the 2 migratory strategies, concluding that neritic and oceanic foragers reach maturity at a similar age.

Whether the observed difference in clutch size ultimately leads to differential lifetime reproductive outcome depends on a number of additional parameters such as variation in within-season clutch size and frequency, reproductive life expectancy and remigration interval (Broderick et al. 2001, Rivalan et al. 2005, Troëng \& Chaloupka 2007). Data on the latter 3 parameters are still too limited at the study site to allow for rigorous testing between the groups. So far we have only considered clutch size of one nesting event, although clutch size seems to remain relatively constant for a given turtle within a season (ARCHELON unpubl. data).

\section{Relative importance of foraging areas}

The frequency estimates of the 2 migratory strategies, based on both described (satellite tracking) and inferred (assignment by stable isotope ratios) foraging location, reveal almost equal importance of the 2 foraging regions for the breeding population and qualitatively support earlier estimates based on potentially biased tag-return data (Margaritoulis et al. 2003) and the smaller sample of tracking of Zbinden et al. (2008). It should be noted, however, that if there is a difference in remigration interval according to foraging area, then the relative contribution of the foraging area with turtles demonstrating the shorter remigration interval would be overestimated.

The difference in isotope signatures between foraging areas was not without slight overlap, and there may be additional major foraging areas as yet undescribed. Of the 2 adult males tracked by Schofield et al. (2009) from Zakynthos over long distances, 1 moved to the Adriatic Sea and 1 off the Aegean coast of Turkey. In the future, the distribution of isotope values in the 2 regions could be better captured by an increased sample size of tracked turtles with known $\delta^{15} \mathrm{~N}$ values, allowing for a robust post hoc Bayesian assignment (Royle \& Rubenstein 2004, Wunder et al. 2005), but the addition of further intrinsic markers would also be desirable. Since the level of industrial activities around the Adriatic Sea is very high (Storelli et al. 2008), concentrations of heavy metals are considered candidate markers here.

\section{CONCLUSIONS}

The established method of linking foraging and breeding areas of a relatively large number of sea turtles not only allows a range of investigations into the 
ecology and biology of the population at present, but may contribute to monitoring these factors over time. For example, a shift in the relative proportion of individuals in a given foraging region observed in the breeding area (which could be correlated to annual nesting population levels and/or other reproductive parameters), as assessed through stable isotope analysis, could be used as an indicator of detrimental changes in one of the foraging regions. Such monitoring over time may become increasingly important given anticipated changes in ecological conditions brought about by climate change (see review by Hawkes et al. 2009, Witt et al. 2010). Stable isotope signatures of turtles foraging in the 2 regions should be monitored over time to discover any shift due, for example, to a change in dietary preference as a result of ecological changes.

In closing, it appears that integrating stable isotope analysis into the study of marine turtle migration holds great promise. As more integrated techniques are used to unravel connectivity, the more likely an adequate understanding of the migratory system will be obtained (Godley et al. 2010). The isotope approach we have outlined here, however, may not necessarily be applied to all breeding populations. A prerequisite is for discrete foraging areas to be characterised by distinct ecological parameters (such as different diet or high anthropogenic influence on source nitrogen as we suggested here for the Adriatic Sea). When such an approach can be successfully applied, it will help take telemetry studies further from the realms of description towards generating meaningful ecological understanding of the species and habitats in question. This is especially important given that many of the recently compiled research priorities for marine turtle conservation and management have a profound spatial component (Hamann et al. 2010). It is highly recommended that sampling for stable isotope (and other chemical markers) analysis becomes a standard procedure integrated with all studies of migratory vertebrates equipped with satellite transmitters.

Acknowledgements. This study was made possible by a grant from the Swiss National Science Foundation to J.A.Z. ('Fellowship for prospective researchers'; grant no. PBBEA117048) as well as significant support by the MAVA Foundation for the Protection of Nature, the Basler Stiftung für Biologische Forschung and the Karl Mayer Foundation. Stable isotope analysis was conducted with analytical support by the UK National Environment Research Council (grant no. EK 123-06/08). We are grateful to F. Korner-Nievergelt of oikostat, Statistical Analyses and Consulting, for providing services in statistical analysis. C. Dean, 2007 project leader, as well as several ARCHELON volunteers are thanked for logistical and practical help. L. Hawkes and R. Inger provided valuable input in data analysis and presentation, and we are grateful for the support by A. C. Broderick throughout the study. M. J. Witt conducted analysis of spatial data and provided extremely useful comments on an earlier version of the manuscript. We acknowledge use of the Maptool program, a product of seaturtle.org (www.seaturtle.org/maptool). J.A.Z. acknowledges the support of R. Arlettaz in the initial satellite tracking study. The comments of 3 anonymous reviewers improved the quality of the manuscript.

\section{LITERATURE CITED}

Arthur KE, Boyle MC, Limpus CJ (2008) Ontogenetic changes in diet and habitat use in green sea turtle (Chelonia mydas) life history. Mar Ecol Prog Ser 362:303-311

Barrow LM, Bjorndal KA, Reich KJ (2008) Effects of preservation method on stable carbon and nitrogen isotope values. Physiol Biochem Zool 81:688-693

Bearhop S, Thompson DR, Waldron S, Russell IC, Alexander G, Furness RW (1999) Stable isotopes indicate the extent of freshwater feeding by cormorants Phalacrocorax carbo shot at inland fisheries in England. J Appl Ecol 36:75-84

Bearhop S, Fiedler W, Furness RW, Votier SC and others (2005) Assortative mating as a mechanism for rapid evolution of a migratory divide. Science 310:502-504

Bjorndal KA (2003) Roles of loggerhead sea turtles in marine ecosystems. In: Witherington BE (ed) Loggerhead sea turtles. Smithsonian Institution, Washington, DC, p 235-254

Block BA, Teo SLH, Walli A, Boustany A and others (2005) Electronic tagging and population structure of Atlantic blue fin tuna. Nature 434:1121-1127

Blumenthal JM, Solomon JL, Bell CD, Austin TJ and others (2006) Satellite tracking highlights the need for international cooperation in marine turtle management. Endang Species Res 2:51-69

Bowen BW, Meylan AB, Ross JP, Limpus CJ, Balazs GH, Avise JC (1992) Global population structure and natural history of the green turtle (Chelonia mydas) in terms of matriarchal phylogeny. Evolution 46:865-881

> Bowen GJ, Wassenaar LI, Hobson KA (2005) Global application of stable hydrogen and oxygen isotopes to wildlife forensics. Oecologia 143:337-348

Broderick AC, Godley BJ, Hays GC (2001) Trophic status drives inter-annual variability in nesting numbers of marine turtles. Proc R Soc Lond B Biol Sci 268:1481-1487

Broderick AC, Glen F, Godley BJ, Hays GC (2003) Variation in reproductive output of marine turtles. J Exp Mar Biol Ecol 288:95-109

> Broderick AC, Coyne MS, Fuller WJ, Glen F, Godley BJ (2007) Fidelity and over-wintering of sea turtles. Proc Biol Sci 274:1533-1538

Casale P, Margaritoulis D (eds) (2010) Sea turtles in the Mediterranean: distribution, threats and conservation priorities. IUCN, Gland

Caut S, Guirlet E, Angulo E, Das K, Girondot M (2008) Isotope analysis reveals foraging area dichotomy for Atlantic leatherback turtles. PloS ONE 3:e1845

> Coyne MS, Godley BJ (2005) Satellite tracking and analysis tool (STAT): an integrated system for archiving, analyzing and mapping animal tracking data. Mar Ecol Prog Ser 301: $1-7$

> Godley BJ, Thompson DR, Waldron S, Furness RW (1998) The trophic status of marine turtles as determined by stable isotope analysis. Mar Ecol Prog Ser 166:277-284

> Godley BJ, Blumenthal JM, Broderick AC, Coyne MS, Godfrey MH, Hawkes LA, Witt MJ (2008) Satellite tracking of sea turtles: Where have we been and where do we go next? Endang Species Res 4:3-22 
Godley BJ, Barbosa C, Bruford M, Broderick AC and others (2010) Unravelling migratory connectivity in marine turtles using multiple methods. J Appl Ecol 47:769-778

Hamann M, Limpus CJ, Owens DW (2003) Reproductive cycles of males and females. In: Lutz PL, Musich JA, Wyneken J (eds) The biology of sea turtles, Vol II. CRC Press, Boca Raton, FL, p 135-161

Hamann M, Godfrey MH, Seminoff JA, Arthur K and others (2010) Global research priorities for sea turtles: informing management and conservation in the 21st century. Endang Species Res 11:245-269

> Hansson S, Hobbie JE, Elmgren R, Larsson U, Fry B, Johansson $\mathrm{S}$ (1997) The stable nitrogen isotope ratio as a marker of food-web interactions and fish migration. Ecology 78: 2249-2257

> Harrington RR, Kennedy BP, Chamberlain CP, Blum JD, Folt CL (1998) ${ }^{15} \mathrm{~N}$ enrichment in agricultural catchments: field patterns and applications to tracking Atlantic salmon (Salmo salar). Chem Geol 147:281-294

> Hatase H, Takai N, Matsuzawa Y, Sakamoto W and others (2002) Size-related differences in feeding habitat use of adult female loggerhead turtles Caretta caretta around Japan determined by stable isotope analysis and satellite telemetry. Mar Ecol Prog Ser 233:273-281

> Hatase H, Sato K, Yamaguchi M, Takahashi K, Tsukamoto K (2006) Individual variation in feeding habitat use by adult female green sea turtles (Chelonia mydas): Are they obligately neritic herbivores? Oecologia 149:52-64

> Hatase H, Omuta K, Tsukamoto K (2010) Oceanic residents, neritic migrants: a possible mechanism underlying foraging dichotomy in adult female loggerhead turtles (Caretta caretta). Mar Biol 157:1337-1342

Hawkes LA, Broderick AC, Godfrey MH, Godley BJ (2009) Climate change and marine turtles. Endang Species Res 7: $137-154$

Hays GC (2000) The implications of variable remigration intervals for the assessment of population size in marine turtles. J Theor Biol 206:221-227

> Hobson KA (1999) Tracing origins and migration. Oecologia 120:314-326

> Inger R, Bearhop S (2008) Applications of stable isotope analyses to avian ecology. Ibis 150:447-461

Margaritoulis D (2005) Nesting activity and reproductive output of loggerhead sea turtles, Caretta caretta, over 19 seasons (1984-2002) at Laganas Bay, Zakynthos, Greece: the largest rookery in the Mediterranean. Chelonian Conserv Biol 4:916-929

Margaritoulis D, Argano R, Baran I, Bentivegna F and others (2003) Loggerhead turtles in the Mediterranean Sea: present knowledge and conservation perspectives. In: Witherington BE (ed) Loggerhead sea turtles. Smithsonian Institution, Washington, DC, p 175-198

Marra PP, Hobson KA, Holmes RT (1998) Linking winter and summer events in a migratory bird by using stable-carbon isotopes. Science 282:1884-1886

McClellan CM, Braun-McNeill J, Avens L, Wallace BP (2010) Stable isotopies confirm a foraging dichotomy in juvenile loggerhead sea turtles. J Exp Mar Biol Ecol 387 : 44-51

Miller JD (1997) Reproduction in sea turtles. In: Lutz PL, Musick JA (eds) The biology of sea turtles, Vol I. CRC Press, Boca Raton, FL, p 51-81

> Norris DR (2005) Carry-over effects and habitat quality in migratory populations. Oikos 109:178-186

Plotkin PT (2003) Adult migrations and habitat use. In: Lutz PL, Musick JA, Wyneken J (eds) The biology of sea turtles, Vol II. CRC Press, Boca Raton, FL, p 225-241
Quillfeldt P, McGill RAR, Furness RW (2005) Diet and foraging areas of Southern Ocean seabirds and their prey inferred from stable isotopes: review and case study of Wilson's storm-petrel. Mar Ecol Prog Ser 295:295-304

R Development Core Team (2007): R: a language and environment for statistical computing. R Foundation for Statistical Computing, Vienna. www.R-project.org

Ramos R, Gonzalez-Solis J, Croxall JP, Oro D, Ruiz X (2009) Understanding oceanic migrations with intrinsic biogeochemical markers. PLoS ONE 4:e6236

Rees AF (2005) ARCHELON, the Sea Turtle Protection Society of Greece: 21 years studying and protecting sea turtles. Testudo 6:32-50

> Rees AF, Al Saady S, Broderick AC, Coyne MS, Papathanasopoulou N, Godley BJ (2010) Behavioural polymorphism in one of the world's largest populations of loggerhead sea turtles, Caretta caretta. Mar Ecol Prog Ser 418: 201-212

> Reich KJ, Bjorndal KA, Bolten AB (2007) The 'lost year' of green turtles: using stable isotopes to study cryptic life stages. Biol Lett 3:712-714

Reich KJ, Bjorndal KA, Frick MG, Witherington BE, Johnson C, Bolten AB (2010) Polymodal foraging in adult female loggerheads (Caretta caretta). Mar Biol 157:113-121

Rivalan P, Prévot-Julliard AC, Choquet R, Pradel R, Jacquemin B, Girondot M (2005) Trade-off between current reproductive effort and delay to next reproduction in the leatherback sea turtle. Oecologia 145:564-574

Rooker JR, Secor DH, De Metrio G, Schloesser R, Block BA, Neilson JD (2008) Natal homing and connectivity in Atlantic bluefin tuna populations. Science 322:742-744

> Royle JA, Rubenstein DR (2004) The role of species abundance in determining breeding origins of migratory birds with stable isotopes. Ecol Appl 14:1780-1788

Rubenstein DR, Hobson KA (2004) From birds to butterflies: animal movement patterns and stable isotopes. Trends Ecol Evol 19:256-263

> Schlacher TA, Liddell B, Gaston TF, Schlacher-Hoenlinger M (2005) Fish track wastewater pollution to estuaries. Oecologia 144:570-584

Schofield G, Katselidis KA, Dimopoulos P, Pantis JD, Hays GC (2006) Behaviour analysis of the loggerhead sea turtle Caretta caretta from in-water observation. Endang Species Res 2:71-79

> Schofield G, Bishop CM, MacLean G, Brown P and others (2007) Novel GPS tracking of sea turtles as a tool for conservation management. J Exp Mar Biol Ecol 347:58-68

Schofield G, Lilley MKS, Bishop CM, Brown P and others (2009) Conservation hotspots: implications of intense spatial area use by breeding male and female loggerheads at the Mediterranean's largest rookery. Endang Species Res 10:191-202

Sterns SC (1992) The evolution of life histories. Oxford University Press, Oxford

> Storelli MM, Barone G, Storelli A, Marcotrigiano GO (2008) Total and subcellular distribution of trace elements $(\mathrm{Cd}, \mathrm{Cu}$ and $\mathrm{Zn}$ ) in the liver and kidney of green turtles (Chelonia mydas) from the Mediterranean Sea. Chemosphere 70 : 908-913

Tomás J, Aznar FJ, Raga JA (2001) Feeding ecology of the loggerhead turtle Caretta caretta in the western Mediterranean. J Zool (Lond) 255:525-532

Troëng S, Chaloupka M (2007) Variation in adult annual survival probability and remigration intervals in sea turtles. Mar Biol 151:1721-1730

> Wallace BP, Seminoff JA, Kilham SS, Spotila JR, Dutton PH (2006) Leatherback turtles as oceanographic indicators: 
stable isotope analyses reveal a trophic dichotomy between ocean basins. Mar Biol 149:953-960

Wallace BP, Avens L, Braun-McNeill J, McClellan CM (2009) The diet composition of immature loggerheads: insights on trophic niche, growth rates, and fisheries interactions. J Exp Mar Biol Ecol 373:50-57

Webster MS, Marra PP, Haig SM, Bensch S, Holmes RT (2002) Links between worlds: unraveling migratory connectivity. Trends Ecol Evol 17:76-83

Wilcove DS, Wikelski M (2008) Going, going, gone: Is animal migration disappearing? PLoS Biol 6:e188

Witt MJ, Hawkes LA, Godfrey MH, Godley BJ, Broderick AC (2010) Predicting the impact of climate change on a globally distributed species: the case of the loggerhead turtle. J Exp Biol 213:901-911

> Witteveen BH, Worthy GAJ, Roth JD (2009) Tracing migratory movements of breeding North Pacific humpback whales

Editorial responsibility: Hans Heinrich Janssen, Oldendorf/Luhe, Germany using stable isotope analysis. Mar Ecol Prog Ser 393: 173-183

Wunder MB, Kester CL, Knopf FL, Rye RO (2005) A test of geographic assignment using isotope tracers in feathers of known origin. Oecologia 144:607-617

> Zbinden JA, Davy C, Margaritoulis D, Arlettaz R (2007a) Large spatial variation and female bias in the estimated sex ratio of loggerhead sea turtle hatchlings of a Mediterranean rookery. Endang Species Res 3:305-312

Zbinden JA, Aebischer A, Margaritoulis D, Arlettaz R (2007b) Insights into the management of sea turtle internesting area through satellite telemetry. Biol Conserv 137:157-162

> Zbinden JA, Aebischer A, Margaritoulis D, Arlettaz R (2008) Important areas at sea for adult loggerhead sea turtles in the Mediterranean Sea: satellite tracking corroborates findings from potentially biased sources. Mar Biol 153: 899-906

Submitted: June 8, 2010; Accepted: October 11, 2010 Proofs received from author(s): December 12, 2010 